\title{
INNOVATIVE AERATION AND TREATMENT TECHNOLOGIES SUPPORTING THE PROCESS OF REVITALIZATION OF DEGRADED WATER RESERVOIRS
}

\author{
Agata Mazur ${ }^{1 凶}$, Krzysztof Chmielowski² $^{2}$ \\ ${ }^{1}$ Department of Geoinformation Photogrammetry and Remote Sensing of Environmen, Faculty of Mining Surveying \\ and Environmental Engineering, AGH University of Science and Technology, al. Mickiewicza 30, 30-059 Kraków \\ 2 Department of Sanitary Engineering and Water Management, University of Agriculture in Kraków, al. Mickiewicza 21, \\ 31-120 Kraków
}

\begin{abstract}
Aim of the study

The study aims were to evaluate the aeration process and MBBR bioreactors operation in the bioremediation process of polluted water reservoirs.
\end{abstract}

\begin{abstract}
Material and methods
The authors presented a review of water reservoir revitalization methods used in industry practice. Fine and microbubble aeration systems are subject to detailed characteristics. There isdescribedthe role of innovative mobile platform systems with MBBR bioreactors in the revitalization of water reservoirs in the article.

\section{Results and conclusion}

Based on the presented scientific information, it has been indicated that the use of effective microaeration and fine bubble aeration systems has a very positive effect on the improvement of the efficiency of revitalization processes. The authors assessed that the indicated methods can only support the main biological method used in the bioremediation of degraded water bodies. The main methods of biological bioremediation was biotechnological methods based on microbiological biopreparations and the formation of eco-barriers (ecotones). A diagram of a prototype rehabilitation platform for water reservoirs is also presented.
\end{abstract}

Keywords: water pollution, MBBR, water treatment, water reservoirs reclamation

\section{INTRODUCTION}

\section{Procedures deciding on the choice of a water revitalization method}

Surface water pollution continues to be a major problem for drinking water resources in many parts of the world. The forms of pollution can be very diverse and constitute a complicated problem for environmen- tal engineers (Dunalska and Wiśniewski, 2016; Mazur et al., 2017; Nowak et al., 2018; Nowak et al., 2019). The scientific and professional literature describes various methods of revitalization and remediation of degraded water reservoirs (Klapper, 2003; Ruan et al., 2006; Dąbrowska, 2008; Faulwetter et al., 2009; Cao, et al., 2012; Dong et al., 2012; Zhao et al., 2012; Gołdyn et al., 2014; Bartoszek \& Koszelnik,

凶e-mail: agata.nowak1992@gmail.com 
2015; Łopata et al., 2016; Lake et al., 2017; Sitarek et al., 2017; Hamilton et al., 2019; Mazur, 2019A). There are no universal systems that would guarantee the restoration of the appropriate quality of degraded waters (Mazur, 2019B). In most cases, an environmental risk assessment (ERA) should be performed before the water renewal process (Mazur, 2020). Assessment procedures depend on latitude, reservoir type, geomorphological conditions, and the nature of the pollution (Robu et al., 2008; Barata et al., 2008; Gómez, 2015). Based on a professionally conducted risk assessment, experts can implement appropriate actions for the ERM (environmental risk management) (Iglesias et al., 2007; Ondiviela et al., 2012). One of the steps of ERM is the selection of appropriate water treatment methods that guarantee that the effects of the reservoir revitalization process will be maintained (Mazur, 2019B). The main aim of the article was to indicate the role of methods supporting the revitalization process of highly polluted water reservoirs. The authors showed that the use of innovative methods of micraeration and biological beds (such as MBBR reactors) has a positive effect on the effectiveness of the treatment process with the application of specific revitalization technologies of the polluted aquatic environment.

\section{Lake revitalization methods}

Although the literature mentions three basic types of methods: chemical, mechanical and biological, hybrid solutions are very often used (see: Table 1) (Hamilton et al., 2019). The development of treatment technology and microbiological biotechnology in the last decade provides new effective tools for the process of renewing polluted waters of water reservoirs (Mazur, 2020). The main advantage of biological methods is the minimization of invasive interference with the fragile balance of aquatic ecosystems, which are already disturbed by the emission of pollutants (Mazur and Sitarek, 2020). In the case of typical water pollutants, where the main problem is the increase in COD or TOC (including DOC) as well as nutrients and suspension, it is recommended to use biopreparations. In order to prevent the excessive supply of nutrients from the process of intensive biodegradation of organic pollutants, ecotones are planted or natural macrophyte formations are used in the reservoir (Sitarek et al., 2017). The species that bioaccumulate nutrients most effectively include i.e. reed (Phragramites Australis), lesser bulrush (Typha angustifolia), broadleaf cattail (Typha latifoliasweet), great manna (Glyceria aquatica), flag (Acorus calamus), and greater pond sedge (Carex riparia) (Mingjun et al., 2009; Dong et al., 2012; Gagnon et al., 2012; Mazur and Sitarek, 2020).

There are degraded water reservoirs with very high loads of organic pollutants, and their intensive biodegradation may cause a secondary eutrophication process. In such situations, the regeneration process is supported by nutrient adsorbents, preferably based on natural minerals (such as zeolites, gethite, etc.), so as not to generate additional forms of chemical pollution at the bottom of the reservoir (Mazur, 2020). Along with the treatment process, sustainable fish management is required, with directional biomanipulation of trophic webs to support the purification process (Mazur and Sitarek, 2020). The elimination of point and area pollution sources is key to reaching the durability of the water treatment effect (Dunalska and Wiśniewski, 2016; Dunalska et al., 2018). Many failures of the revitalization process result from negligence in eliminating sources of pollution, and not from the selection of methods (Mazur, 2020). The treatment process itself is also significantly impeded, and despite the implemented measures and temporary improvement, the process may be completely disturbed (Mazur and Sitarek, 2020). Then, ad hoc chemical methods are used, unfortunately with adverse long-term consequences for aquatic ecosystems (Goldyn et al., 2014; Bartoszek and Koszelnik, 2015; Augustyniak et al., 2019). The by-products of the nutrient flocculation process accumulate in bottom sediments and may adversely affect the reproduction process of various aquatic species, including fish. The toxicological effects of these products may appear also in conditions of strong sediment disturbance and secondary intoxication of the reservoir water (Pottinger et al., 20111; Mazur et al., 2020). 
Mazur, A., Chmielowski, K. (2020). Innovative aeration and treatment technologies supporting the process of revitalization of degraded water reservoirs. Acta Sci. Pol., Formatio Circumiectus, 19 (3), 15-28. DOI: http://dx.doi.org/10.15576/ASP.FC/2020.19.3.15

Table 1. A list of the most common methods used in the remediation of water reservoirs in the world

Water Reservoir Remediation Engineering (directly into lake water)

\begin{tabular}{|c|c|c|}
\hline Biological Techniques & Chemical Techniques & Mechanical Techniques \\
\hline $\begin{array}{l}\text { Natural wetlands (natural community } \\
\text { of water macrophytes) } \\
\text { Constructed wetlands in-situ } \\
\text { (ecotones) based on the planting of } \\
\text { selected species of helophytes etc. } \\
\text { Biomanipulation methods of } \\
\text { controlling the aquatic animals and } \\
\text { plants } \\
\text { - bottom-up } \\
\text { - up-to-down } \\
\text { Application of microbiological } \\
\text { biopreparation (solid and liquid form) } \\
\text { - alohtonus strains (an consortia } \\
\text { of microorganism with suitable } \\
\text { nutrients) } \\
\text { - autochthonous strains selected from } \\
\text { environmental samples } \\
\text { EM for water treatment: FLO- } \\
\text { 1200, ACS aqua, Eco Tabs }{ }^{\mathrm{TM}} \text { and } \\
\text { other } \\
\text { EM for soft organic sediment } \\
\text { biodegradation: ACS ODO, } \\
\text { Greenland EM and other }\end{array}$ & 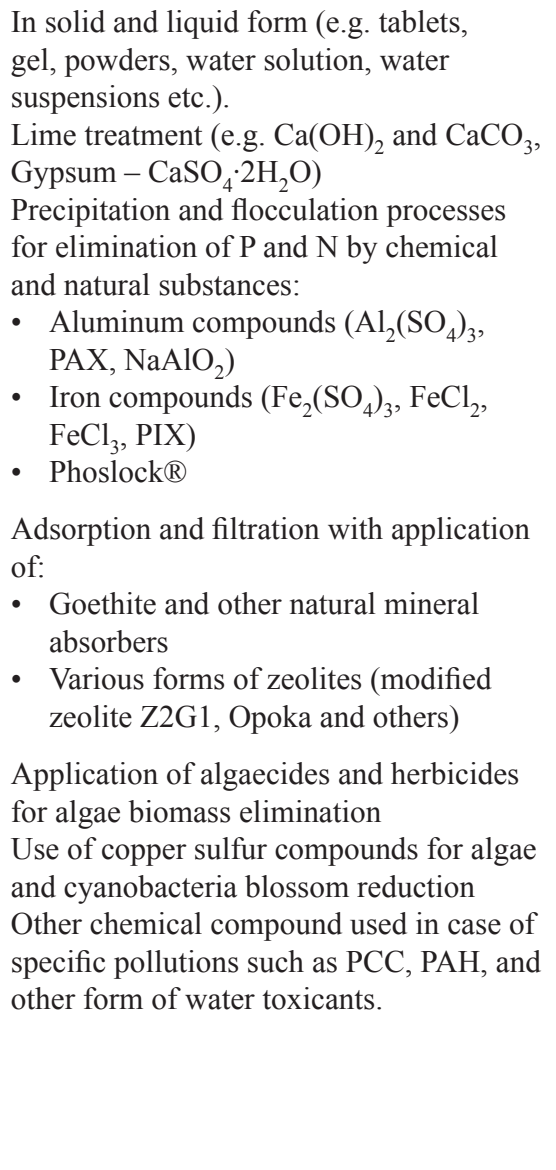 & $\begin{array}{l}\text { Flushing - bottom sediment removal } \\
\text { (several methods) } \\
\text { Dredging or deepening - with } \\
\text { elimination all polluted sediment layer } \\
\text { (several methods) } \\
\text { Lake drawdown (many methods) } \\
\text { Seepage trenches and filter basins } \\
\text { (several techniques) } \\
\text { Sediment extraction - after emptied } \\
\text { reservoir } \\
\text { Removal of water from hypolimnion } \\
\text { Aeration (several methods) } \\
\text { - linear aeration at various depths } \\
\text { (micro, fine and coarse bubble } \\
\text { diffusors) } \\
\text { - point aeration (creating an island of } \\
\text { life) } \\
\text { - electromagnetic resonators } \\
\text { - hypolimnetic aeration with artificial } \\
\text { destratification } \\
\text { - hypolimnetic aeration without } \\
\text { disturbing the temperature } \\
\text { stratification } \\
\text { Sediment oxidation } \\
\text { Sediment covering (Lake bottom } \\
\text { sealing) (many membrane material and } \\
\text { techniques) } \\
\text { Mechanical harvesting of biomass }\end{array}$ \\
\hline
\end{tabular}

Source: (Singh, 1982; Hamby, 1996; Ruan et al., 2006; Hadad et al., 2006; Chitrakar et al., 2006; Chmielowski \& Slizowski, 2008; Juang et al., 2008; Dąbrowska, 2008; Mingjun et al., 2009; Faulwetter et al., 2009; Xiao et al., 2010; Cao et al., 2012; Dong et al., 2012; Gagnon et al., 2012; Sheng et al., 2012; Zhao et al., 2012; Fan et al., 2013; Bartoszek and Koszelnik, 2015; Nasr and Ismail, 2015; Ateia et al., 2016; Mazur et al., 2016; Kaczor et al., 2017; Wsik et al., 2017; Zawadzki et al., 2017; Mazur and Sitarek, 2020; Mazur, 2020; Mazurkiewicz et al., 2020).

\section{HEAVILY DEGRADED RESERVOIRS}

In industrial and agricultural areas in Poland, there are many highly degraded water reservoirs, and the nature of the pollution is very complex (Rybicka, 1996). Water in such reservoirs is often toxic to many species of aquatic organisms. We observe a very low level of biodiversity in the aquatic environment (Polkowska et al., 2000; Yüksek et al., 2006; Dudgeon et al., 2006; Kowal- czak and Kundzewicz, 2011; Dobrowolski et al., 2012). Such reservoirs show high toxicological variability in the season, depending on weather factors (mainly water levels and precipitation). In periods of low flows, the concentration of mixtures of water toxins often increases (Chattopadhyay and Banerjee, 2007). In a polluted aquatic environment, tolerant species survive and those that have adapted to specific groups of pollutants in long-term periods (Van Aalst et al., 2008). 
ERM procedures in this type of cases are developed individually for each facility, and the revitalization process is monitored on-line. The selection of methods must take into account comprehensive measures aimed at the elimination of pollutants in water, bottom sediments and the elimination of potential sources of their emissions (Mazur, 2020).

Due to the nature of the mixture of pollutants, the following treatments are used:

- mechanical, e.g. silting of bottom sediments, etc. and treatment of leachate in separate technological lines (sewage treatment plants and pre-treatment plants built in side technological pools as well as sedimentation reservoirs and presses for dewatering highly toxic sediments), the sediments are disposed depending on their contamination composition

- linear aeration systems in a water reservoir (fine and microbubble aeration): a highly efficient system (Chmielowski et al., 2019)

- aeration with electro-magnetic resonator system: a system with lower efficiency

- biotechnological (application of directional biopreparations) in liquid (e.g. EM) or solid form (e.g. Eco-tabs or powders with freeze-dried microorganisms from the group of extremophiles)

- biological: creating barriers of helophytes species, working as wetlands, which additionally purify selected groups of pollutants and adsorb the excessive supply of nutrients

- auxiliary chemical methods may be necessary, i.e. the use of selected coagulants to precipitate phosphorus into the bottom sediments

Revitalization processes of this type of facilities are extremely expensive, depending on the loads and forms of pollution, the price of revitalization of 1 ha of a lake ranges from several hundred thousand to several million euro (Bernhardt et al., 2005). An example of this type of polluted lakes is the Kalina Pond in Świętochłowice, whose loads of various organic compounds, mainly petroleum derivatives caused complete degradation of the aquatic environment (see: Fig. 1). The process of revitalizing 6 ha of the reservoir requires hybrid methods, and the costs are ca. EUR 20 million. The contamination of this reservoir persists for several dozen years and is the result of industrial coal mining processes and improper dispos- al methods of various liquid waste substances (containing various types of petroleum derivatives). The process of ground pollution emission lasted from the period before the Second World War, when this area belonged to the German state. After the war, unsustainable industrial economy was continued and hazardous waste was stored in heaps by the reservoir.

\section{AQUACULTURE WITH HIGH FISH STOCKS}

Fish ponds, depending on the stocking density and population density of commercial fish, require a particularly high level of water treatment and monitoring. Slight changes in the level of $\mathrm{pH}$, conductivity and redox can significantly affect the rate of fish growth and their vital parameters, including resistance to a number of pathogens. The concentration of oxygen in the water also plays a key role in the health condition of the fish (different species have varying tolerances). In order to maintain optimal welfare of the population, breeders try to keep the oxygen concentration within 6 or more $\mathrm{mg} \mathrm{O}_{2} / 1$, and the survival limit is $3 \mathrm{mg} \mathrm{O}_{2} / 1$ and lower (Swann, 1997). Intensive breeding is associated with a high feed input and intensive production of manure, which makes it particularly difficult to maintain the quality of water for breeding (see: Fig. 2).

The process of water treatment and treatment for breeding purposes requires efficient aeration and filtration systems on biological beds. Separate biological treatment plants are built in the breeding pools, in which biological treatment processes are carried out in the nitrification and denitrification mode (Nowak et al., 2018). Treatments of this type in natural reservoirs are difficult, and the purification process must be carried out in a lake (Mazur, 2019). Mechanical desludging and revitalization operations are possible after the end of the season and fish harvesting, but they cannot be performed during the breeding season.

The aeration process itself may not be sufficient as the nitrification process generates significant loads of nitrates in the water, which also have a negative effect on the welfare of the fish. It is required to introduce additional mobile treatment installations in the pond, which can effectively condition the water to the quality necessary for the fish of a given species. In industry practice, additional applications are used with selected directional biopreparations supporting treatment 
Mazur, A., Chmielowski, K. (2020). Innovative aeration and treatment technologies supporting the process of revitalization of degraded water reservoirs. Acta Sci. Pol., Formatio Circumiectus, 19 (3), 15-28. DOI: http://dx.doi.org/10.15576/ASP.FC/2020.19.3.15
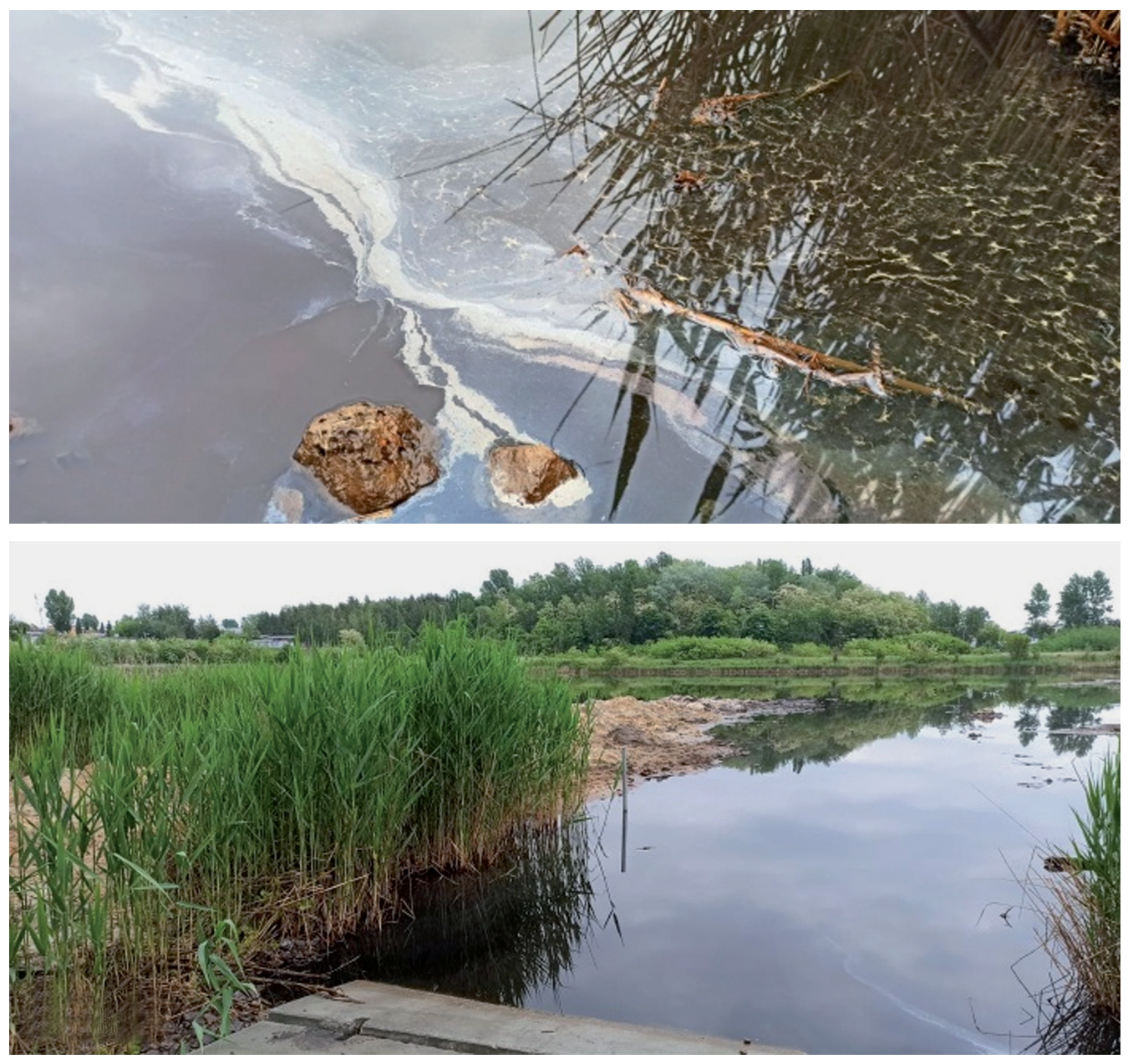

Fig. 1. Degraded Lake Kalina in Silesia in Poland, very poor biodiversity level in water environment (photo by A. Mazur).

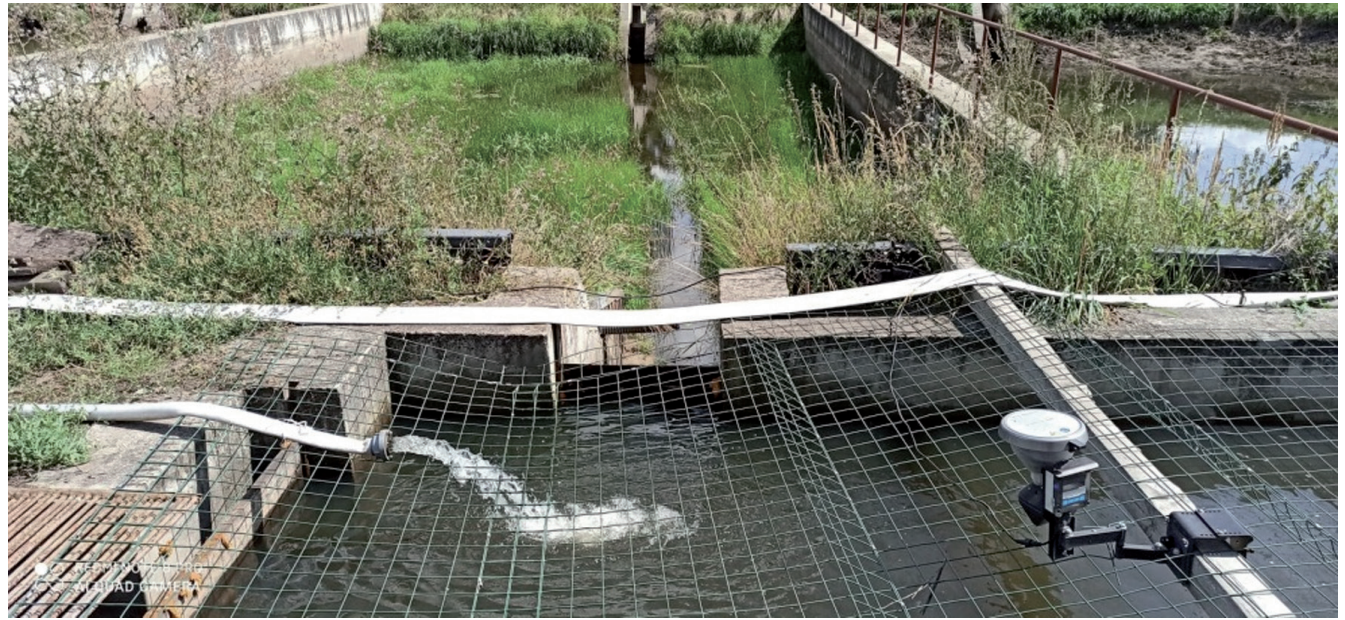

Fig. 2. A breeding pond with a high stocking population of Acipenser oxyrinchus (photo by A. Mazur) 
processes. Many manufacturers of microbiological biopreparations report that these products are able to eliminate selected fish pathogens.

\section{Technologies supporting in-situ treatment}

Environmental conditions characteristic of water bodies require methods and technologies with high tolerance to changes in environmental conditions. Treatment processes under temperate and moderately cool climate conditions are limited to the growing season when the water temperature does not drop below $4^{\circ} \mathrm{C}$, for more than one day (Mazur, 2019 b). Few of the industrial processes used in the treatment of municipal and industrial wastewater can be adapted to such conditions.

\section{Linear aeration installations}

The most frequently used processes include fine-bubble linear aeration. The process of direct water aeration improves aerobic conditions for microorganisms involved in the biodegradation processes of organic pollutants (Gafsi et al., 2009; Anber et al., 2020). The disadvantage of this type of aeration line is the shallow depth of many contaminated fish reservoirs or ponds. In this type of facility, the aeration efficiency is significantly worse and the energy expenditure and aeration costs increase significantly (Zdorovennova et al., 2016).

The dynamic development of the industry of materials used in the construction of diffusers provides new solutions that allow the process of microbubble aeration at relatively low opening pressures of the pores of diffuser membranes (Chmielowski et al., 2019). Industry companies supply the market with ready-made solutions for microbubble aeration in aeration lines. Microbubble installations are able to effectively aerate shallow reservoirs and maintain optimal conditions for the development of the most demanding organisms in aquaculture (Wei et al., 2004). Biodegradation of pollutants by microorganisms introduced into polluted reservoirs is very intense and effective. In the initial stages of treatment, ecotic and natural macrophyte formations are not able to adsorb the excess supply of nutrients from the intensive nitrification process. With high loads of accumulated pollutants in the revitalization process, it is required to support nutrient uptake by using additional absorbents (preferably natural, mineral-based). In the lakes, foaming processes can also occur in the first stage of revitalization, which subside in the following stages (see: Fig. 3).

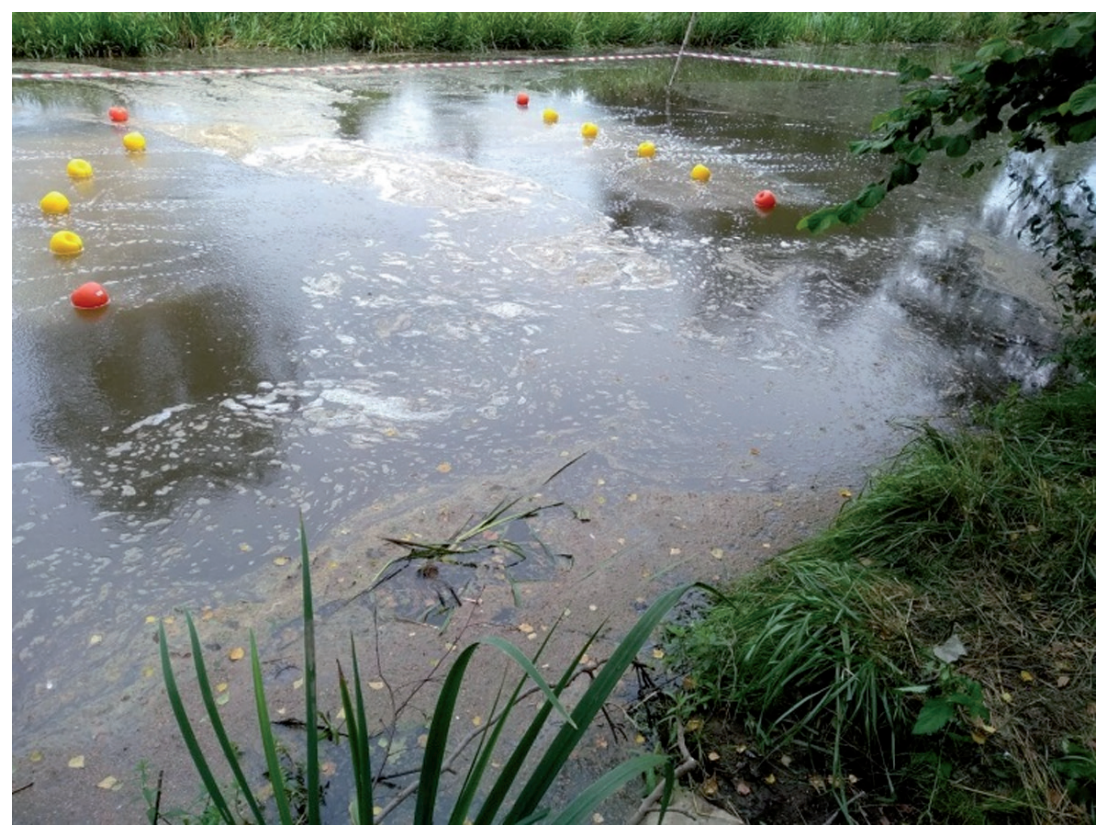

Fig. 3. Microaeration process by ACS Poland on the Ożanna Lake supply river channel, during the 2020-2022 revitalization process (photo by P. Karwowski). 
The location of diffusers should not be too close to bottom sediments, so as not to disturb the sediment and deteriorate the parameters of light transmission in the water. The microbubble aeration process is characterized by laminar flows and negligible turbulence, yet light suspensions are able to circulate with this type of aeration.

\section{Application of biomass carriers in MBBR reactors}

The scientific literature describes the first attempts to use bioreactors in the process of surface water rejuvenation (in situ) (Li et al., 2010; Ateia et al., 2015; 2016; Nowak et al., 2019).

The advantages of MBBR (moving bed biofilm reactor) reactors include high tolerance to water temperature changes and heterogeneity of charges during the treatment process (Andreottola et al., 2000; Ødegaard, 2004; Leiknes and Ødegaard, 2007; McQuarrie and Boltz, 2011). The efficiency of the reactors depends, inter alia, on the types of moving beds (biomass carriers) used (Kujawiak et al., 2017, 2018, 2020). New moving bed technologies, e.g. Mutag Biochips 30 fittings, are one of the most effective carriers for various types of biofilms (artificial microbial ecosystems) with both high and low substrate affinity (see: Fig. 4) (Gogina and Quan, 2020).

This type of carriers can work both with high loads of pollutants and remain effective when the concentrations of these pollutants decrease. The filling of the bioreactor bed, when using traditional fittings, e.g. Kaldness, ranges from $40 \%$ to $60 \%$ of the reactor chamber (see: Fig. 5). Mutag Biochips 30 biological beds guarantee an efficient treatment process with a filling of $15-20 \%$.

The disadvantages of installing MBBR bioreactors in lake conditions include:

- point location and limited level of pollutant intake

- it only determines the zonal nature of effective treatment

- bioreactors should be flooded and in periods of low water flow they may lose hydraulic efficiency

- they require power supply for blowers and elements anchoring to the data or floating platforms in which they are installed

Despite technological limitations, this type of reactors can be a significant supplement to the linear aeration system. In a system with an aeration line and continuous dosing of biopreparations to the MBBR biological beds, bioreactors located in a lake environment create hybrid incubators stimulating the growth of microorganisms (see: Fig. 6). Retention of microorganisms outside the bioreactor system continuously provides effective microflora involved in cleaning processes, especially in the zone of intense aeration (Nowak et al., 2019). The feed system may include a common compressed air separation plant for the in-line aeration system and the in-situ supply of MBBR diffusers.

It is also possible to adapt PV technology to power lake blowers on mobile reclamation platforms (see: Fig. 7).

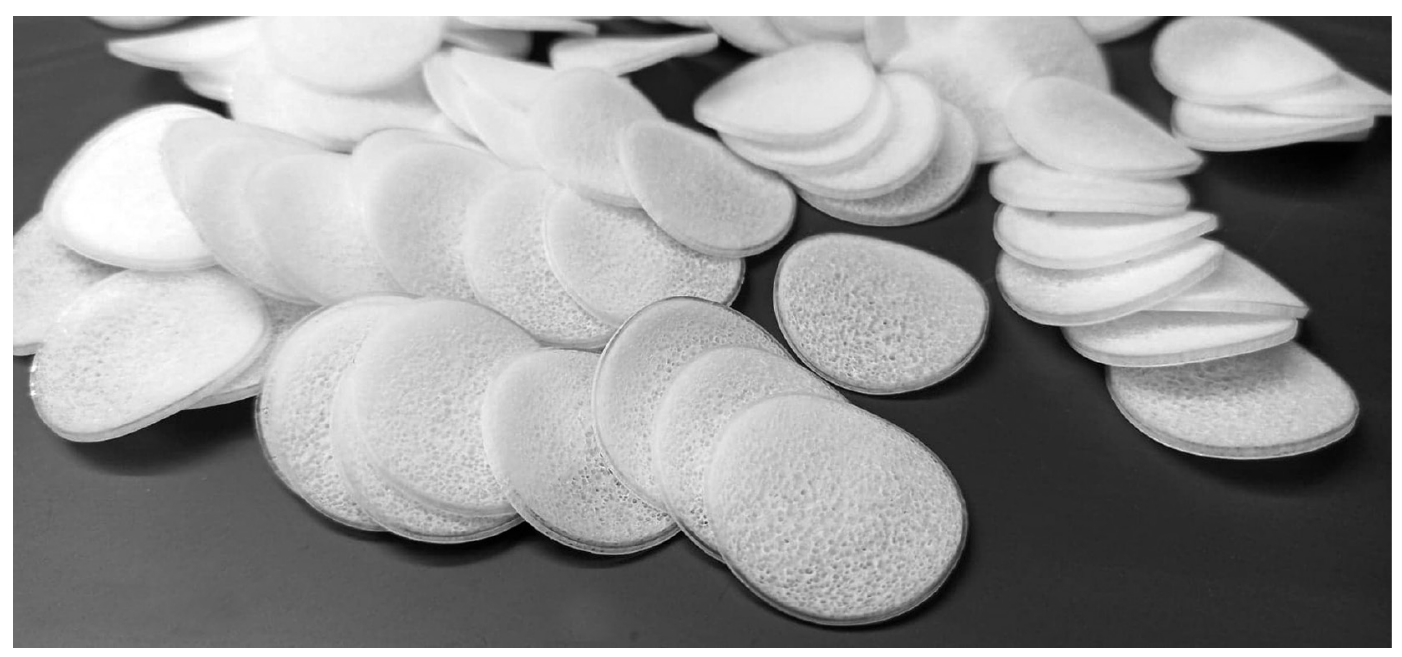

Fig. 4. Mutag Biochips 30 biomass carriers by Multi Umwelttechnologie AG (photo by A. Mazur) 
Mazur, A., Chmielowski, K. (2020). Innovative aeration and treatment technologies supporting the process of revitalization of degraded water reservoirs. Acta Sci. Pol., Formatio Circumiectus, 19 (3), 15-28. DOI: http://dx.doi.org/10.15576/ASP.FC/2020.19.3.15
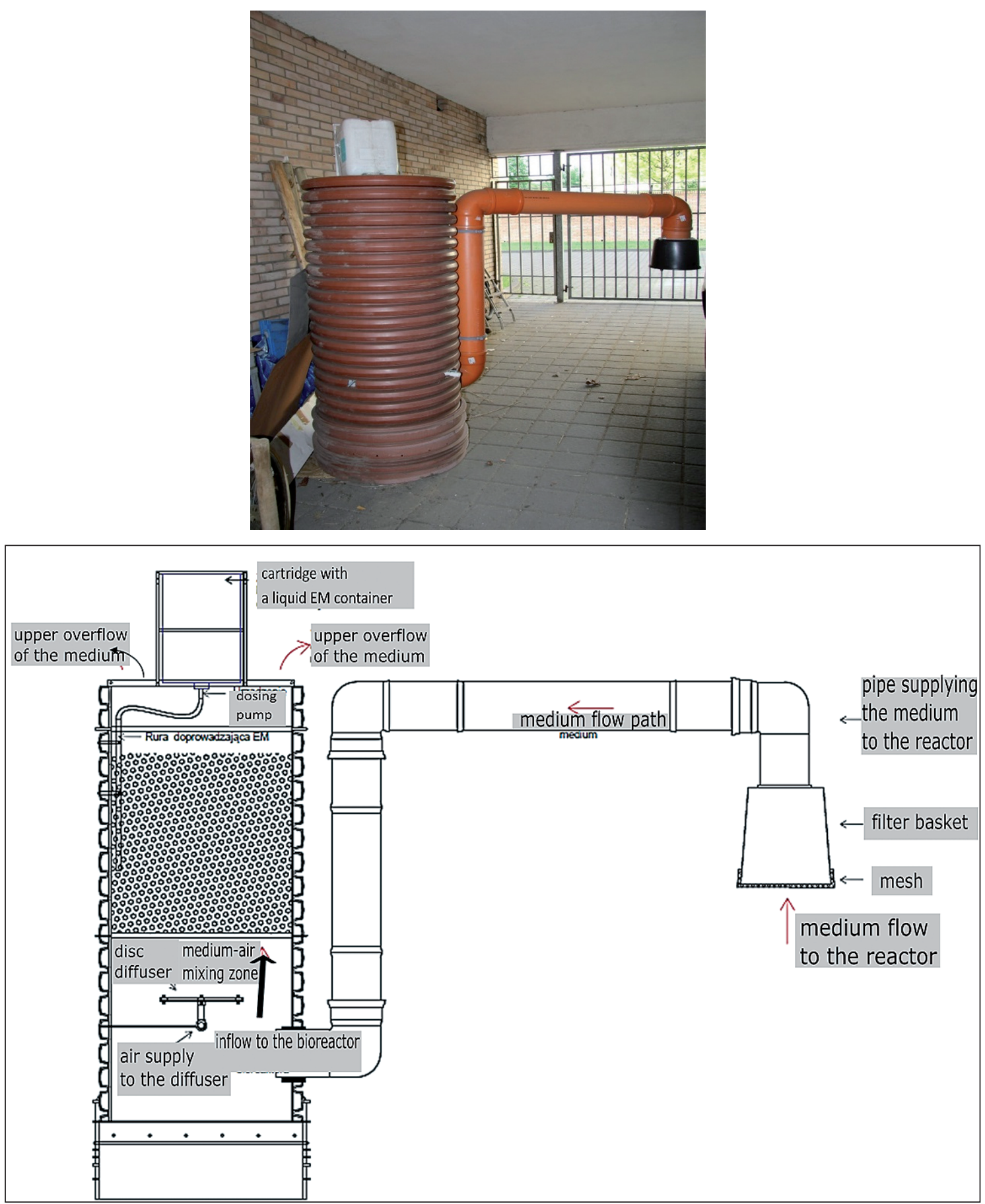

Fig. 5. Diagram of the submersible MBBR reactor to support the revitalization processes of small water reservoirs (A. Mazur), with the Kaldness biological bed 


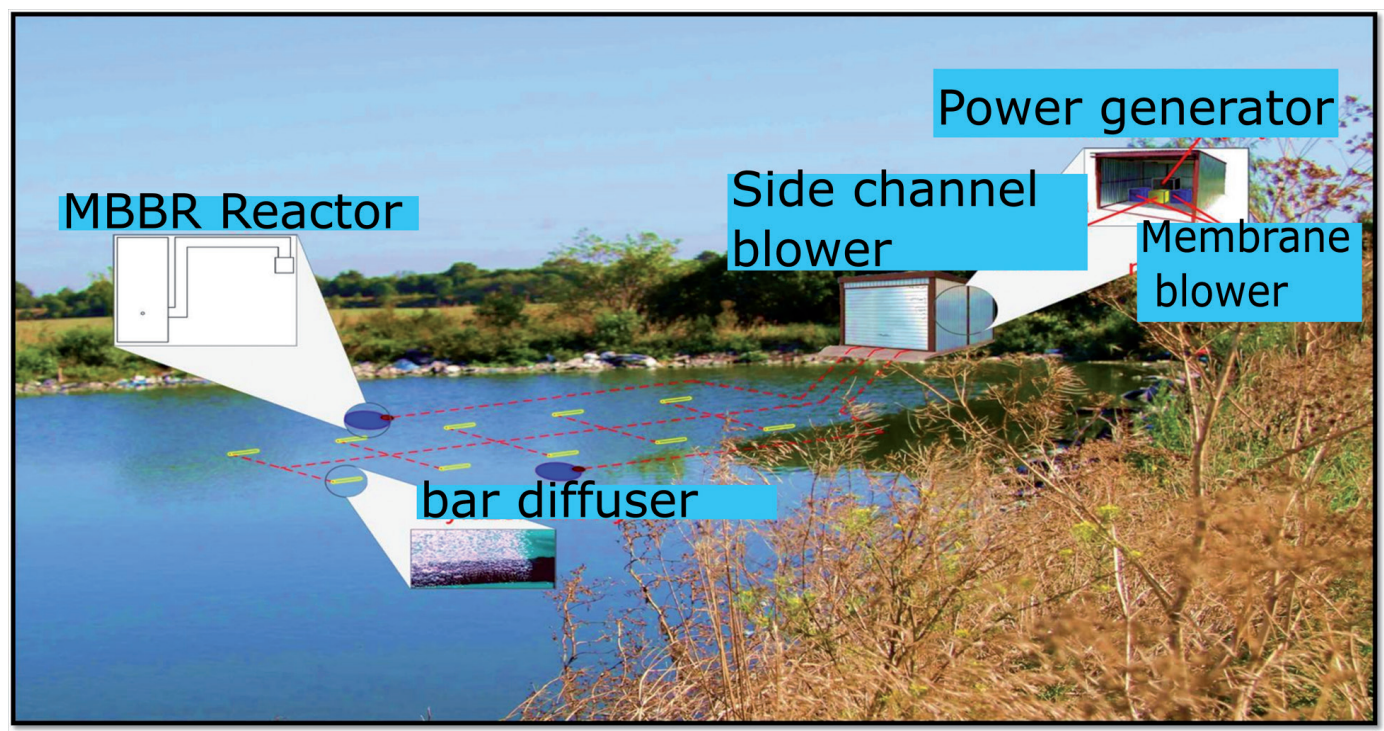

Fig. 6. MBBR system in a system with a microbubble aeration line operating in a degraded band reservoir at a landfill. (photo by: A. Mazur)

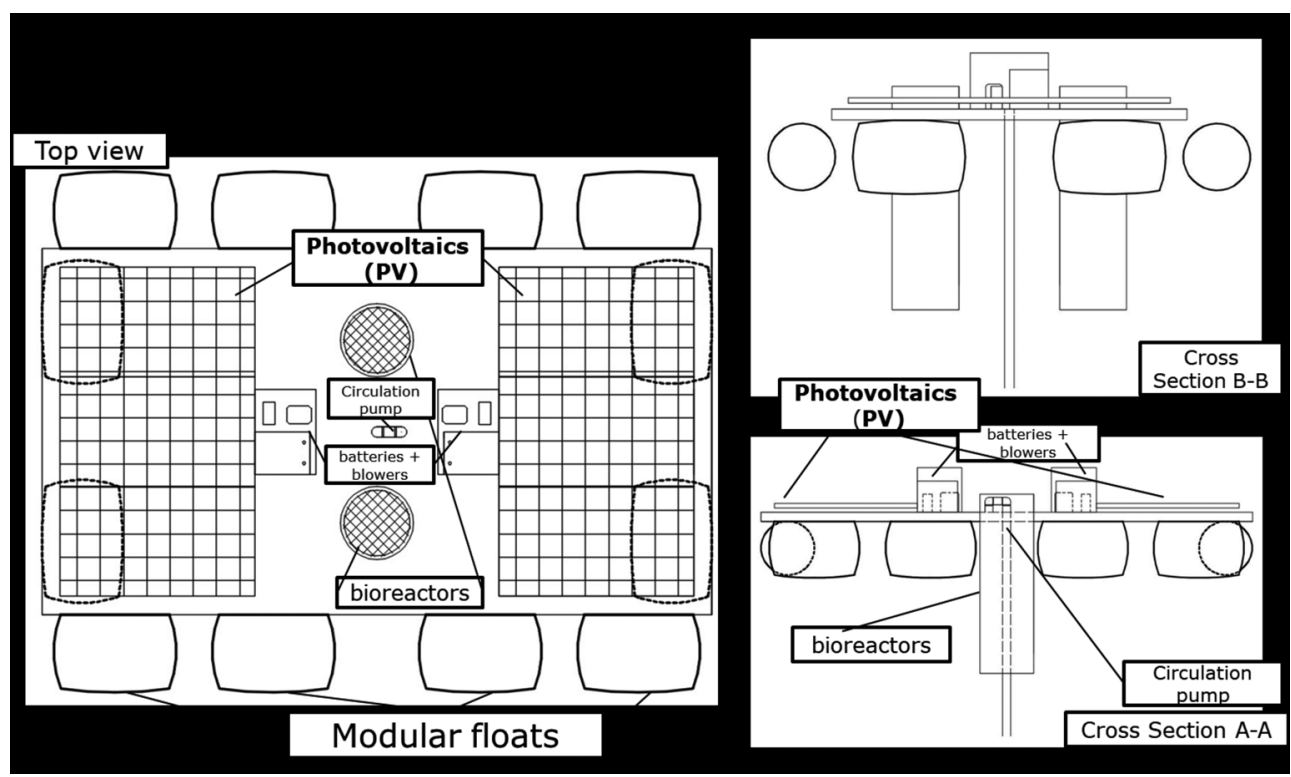

Fig. 7. Diagram of a mobile reclamation platform with MBBR reactors powered by renewable sources (PV) (photo by R. Mazur and A. Mazur)

Energy storage in water conditions on the lake requires special protection and the use of types of batteries safe for the aquatic environment. There are new types of silicone batteries on the market with better electricity charging efficiency compared to traditional batteries.

\section{DISCUSSION}

The discussed in the article methods supporting the treatment processes can significantly accelerate the process of cleaning highly polluted waters of small 
and large reservoirs during the growing season. Two key systems have been presented that are compatible and complement each other. MBBR bioreactors cooperating with the microbubble aeration system will undoubtedly stimulate the reservoir cleaning process. The application of biopreparations to the aquatic environment requires time for the adaptation of microorganisms to the conditions in the reservoir, and the treatments are often repeated at a high level of pollution loads (Sitarek et al., 2017; Mazur, 2020; Mazur and Sitarek, 2020). In the waters of heavily polluted reservoirs, anoxic conditions are very often present, which significantly hinder the process of alohthonous microorganisms from efficiently integrating and biodegrading organic pollutants (Grochowska and Gawronska, 2004; Das, 2005). In such conditions, supporting processes may decide whether the undertaken revitalization activities are successful (Klapper, 2003). It is also possible to significantly accelerate water purification, which in the case of utility reservoirs (bathing areas, fisheries, water abstraction zones for consumer purposes) is very beneficial and translates into measurable financial benefits (Dixit et al., 2007; Cantor and Director, 2007; Łopata et al., 2016).

Aeration not only stimulates aerobic microorganisms to efficiently convert organic compounds into a mineral form, but also supports the revival of organisms that cannot survive in anaerobic conditions (Carr and Martin, 1978; Muhammetoğlu et al., 2002). The increase in biodiversity is a key factor in stabilizing the fragile balance of aquatic ecosystems (Bürgi and Stadelmann, 2002; Lake et al., 2007; Gołdyn et al., 2014). It is possible to significantly improve the functioning of the treatment and aeration installation by locating it on a mobile reclamation platform. Similar vessel filter bioreactor systems have been used in Japan to filter algae from the waters of heavily eutrophied lakes (Tanaka et al., 2001). The applied treatment filters performed rather mechanical filtration functions, but in the mobile platform system the scope of their operation was many times greater than in the stationary system (Tanaka et al., 2001; Nakamura and Mueller, 2008). The authors used power from renewable sources, from PV panels mounted on the unit. Many innovative solutions that can be used in the installation of energy self-sufficient platforms for revitalization of lakes are provided by the development of the Solar-Boat technology (Spagnolo et al., 2012; Naszrudin et al., 2017; Kapuścik et al., 2019).

\section{CONCLUSIONS}

There are scientific indications of a dynamic development of innovative technologies, aeration and treatment in MMBR reactors, which can be adapted to the processes of revitalization of degraded water bodies. Supporting the process of biodegradation of organic pollutants in a water reservoir by an aeration and treatment system (MBBR) may increase the chances of a successful lake regeneration. The applied system can also speed up the cleaning and operation of the reservoir in accordance with specific utility functions. The construction of energy-self-sufficient reclamation platforms will make it possible to increase the range and efficiency of its operation in the area of the degraded water reservoir. The hydraulic tests of the MBBR bioreactor confirm its use in the in situ treatment process in the conditions of contaminated water reservoirs.

\section{REFERENCES}

Anber, F., Iqra, N. A., \& Badruzzaman, A. B. M. (2020, April). Restoration of Hatirjheel Lake by designing submerged aeration system and settling zone. In IOP Conference Series: Earth and Environmental Science ( 476, 1, p. 012138). IOP Publishing.

Andreottola, G., Foladori, P., Ragazzi, M., \& Tatano, F. (2000). Experimental comparison between MBBR and activated sludge system for the treatment of municipal wastewater. Water Science \& Technology, 41(4), 375-382 .

Ateia M, Nasr M, Yoshimura C, Fujii M (2015) Organic Matter Removal from Saline Agricultural Drainage Wastewater Using a Moving Bed Biofilm Reactor. Water Science \& Technology, 72, 1327-1333

Ateia, M., Yoshimura, C., \& Nasr, M. (2016). In-situ biological water treatment technologies for environmental remediation: a review. J Bioremed Biodeg, 7(348), 2.

Augustyniak, R., Grochowska, J., Łopata, M., Parszuto, K., Tandyrak, R., \& Tunowski, J. (2019). Sorption properties of the bottom sediment of a lake restored by phosphorus inactivation method 15 years after the termination of lake restoration procedures. Water, 11(10), 2175. 
Mazur, A., Chmielowski, K. (2020). Innovative aeration and treatment technologies supporting the process of revitalization of degraded water reservoirs. Acta Sci. Pol., Formatio Circumiectus, 19 (3), 15-28. DOI: http://dx.doi.org/10.15576/ASP.FC/2020.19.3.15

Barata, C., Alanon, P., Gutierrez-Alonso, S., Riva, M. C., Fernández, C., \& Tarazona, J. V. (2008). A Daphnia magna feeding bioassay as a cost effective and ecological relevant sublethal toxicity test for environmental risk assessment of toxic effluents. Science of the total environment, 405(1-3), 78-86.

Bartoszek, L., Koszelnik, P. (2015). Lakes and reservoirs restoration-Short description of the chosen methods. Progress in Environmental Engineering, 51.

Bernhardt, E. S., Palmer, M. A., Allan, J. D., Alexander, G., Barnas, K., Brooks, S., Galat, D. (2005). Synthesizing US river restoration efforts. Science. 308 (5722), 636-637.

Bürgi, H., Stadelmann, P. (2002). Change of phytoplankton composition and biodiversity in Lake Sempach before and during restoration. Hydrobiologia, 469(1-3), 33-48.

Cantor, M. R., Director, L. I. E. (2007). Economic impact of regional beach closings on the long island economy.

Cao W, Zhang H, Wang Y, Pan J (2012) Bioremediation of polluted surface water by using biofilms on filamentous bamboo. Ecological engineering, 42, 146-149.

Carr, J. E., \& Martin, D. F. (1978). Aeration efficiency as a means of comparing devices for lake restoration. Journal of Environmental Science \& Health Part A, 13(1), $73-85$

Chattopadhyay, C., \& Banerjee, T. C. (2007). Temporal changes in environmental characteristics and diversity of net phytoplankton in a freshwater lake. Turkish Journal of Botany, 31(4), 287-296.

Chitrakar, R., Tezuka, S., Sonoda, A., Sakane, K., Ooi, K., \& Hirotsu, T. (2006). Phosphate adsorption on synthetic goethite and akaganeite. Journal of colloid and interface science, 298(2), 602-608.

Chmielowski, K., \& Slizowski, R. (2008). Effect of grainsize distribution of sand on the filtrate quality in vertical-flow filters. Przemysł Chemiczny, 87(5), 432-434.

Chmielowski, K., Mazur, R., \& Dacewicz, E. (2019). Studies on the effectiveness of wastewater aeration with application of new technologies of micro-bubble diffusers. Przemysł Chemiczny, 98(9), 1392-1394.

Dąbrowska, J. (2008). Methods of reclamation of water reservoirs. Acta Sci Pol Formatio Circumiectus, 7(1), 63-79.

Das, B. K. (2005). Environmental pollution impact on water and sediments of Kumaun lakes, Lesser Himalaya, India: a comparative study. Environmental Geology, 49(2), 230-239.

Dixit, S., Verma, N., Tiwari, S., \& Mishra, D. D. (2007). An innovative technique for lake management with reference to aeration unit installed at lower lake, Bhopal, India. Environmental monitoring and assessment, 124(1-3), 33-37.
Dobrowolski, J. W., Śliwka, M., \& Mazur, R. (2012). Laser biotechnology for more efficient bioremediation, protection of aquatic ecosystems and reclamation of contaminated areas. Journal of Chemical Technology \& Biotechnology, 87(9), 1354-1359.

Dong H, Qiang Z, Li T, Jin H, Chen W (2012) Effect of artificial aeration on the performance of vertical-flow constructed wetland treating heavily polluted river water. Journal of Environmental Sciences, 24, 596-601.

Dudgeon, D., Arthington, A. H., Gessner, M. O., Kawabata, Z. I., Knowler, D. J., Lévêque, C., Sullivan, C. A. (2006). Freshwater biodiversity: importance, threats, status and conservation challenges. Biological reviews, 81(2), 163-182.

Dunalska, J. A., Wiśniewski, G. (2016). Can we stop the degradation of lakes? Innovative approaches in lake restoration. Ecological Engineering, 95, 714-722.

Fan J, Zhang B, Zhang J, Ngo HH, Guo W, et al. (2013) Intermittent aeration strategy to enhance organics and nitrogen removal in subsurface flow constructed wetlands. Bioresour Technol, 141, 117-122.

Faulwetter JL, Gagnon V, Sundberg C, Chazarenc F, Burr $\mathrm{MD}$, et al. (2009) Microbial processes influencing performance of treatment wetlands: a review. Ecological engineering, 35, 987-1004.

Gafsi, M., Kettab, A., Benmamar, S., \& Benziada, S. (2009). Comparative studies of the different mechanical oxygenation systems used in the restoration of lakes and reservoirs. J. Food Agric. Environ, 7(2), 815-822.

Gagnon V, Chazarenc F, Kõiv M, Brisson J (2012) Effect of plant species on water quality at the outlet of a sludge treatment wetland. Water Res 46: 5305-5315.

Gogina, E., \& Quan, T. H. (2020, June). The nitrifying rate of Sequencing Batch Reactor when apply bio-carrier the Biochip to municipal wastewater treatment. In IOP Conference Series: Materials Science and Engineering (869, 4, p. 042013). IOP Publishing.

Gołdyn, R., Podsiadłowski, S., Dondajewska, R., \& Kozak, A. (2014). The sustainable restoration of lakes-towards the challenges of the Water Framework Directive. Ecohydrology \& Hydrobiology, 14(1), 68-74.

Gómez, A. G., Ondiviela, B., Puente, A., \& Juanes, J. A. (2015). Environmental risk assessment of water quality in harbor areas: A new methodology applied to European ports. Journal of environmental management, 155, 77-88.

Grochowska, J., Gawronska, H. (2004). Restoration effectiveness of a degraded lake using multi-year artificial aeration. Polish Journal of Environmental Studies, 13(6) 
Mazur, A., Chmielowski, K. (2020). Innovative aeration and treatment technologies supporting the process of revitalization of degraded water reservoirs. Acta Sci. Pol., Formatio Circumiectus, 19 (3), 15-28. DOI: http://dx.doi.org/10.15576/ASP.FC/2020.19.3.15

Hadad HR, Maine MA, Bonetto CA (2006) Macrophyte growth in a pilot-scale constructed wetland for industrial wastewater treatment. Chemosphere, 63, 1744$-1753$.

Hamby D. (1996) Site remediation techniques supporting environmental restoration activities-a review. Science of The Total Environment, 191, 203-224.

Hamilton, D. P., Collier, K. J., Quinn, J. M., \& Howard-Williams, C. (Eds.). (2019). Lake restoration handbook: A New Zealand perspective. Springer.

Iglesias, A., Garrote, L., Flores, F., \& Moneo, M. (2007). Challenges to manage the risk of water scarcity and climate change in the Mediterranean. Water resources management, 21(5), 775-788.

Juang D, Tsai W, Liu W, Lin J (2008) Treatment of polluted river water by a gravel contact oxidation system constructed under riverbed. International Journal of Environmental Science Technology, 5, 305-314.

Kaczor, G., Chmielowski, K., \& Bugajski, P. (2017). The effect of total annual precipitation on the volume of accidental water entering sanitary sewage system. ROCZNIK OCHRONA SRODOWISKA, 19, 668-681.

Kapuścik, W., Maraszek, J., Borowicz, M., \& Sornek, K. (2019, January). AGH Solar Boat-the analysis of energy and ecological parameters of the solar powered boat. In IOP Conference Series: Earth and Environmental Science (214, 1, p. 012143). IOP Publishing.

Klapper, H. (2003). Technologies for lake restoration. In Papers from Bolsena Conference (2002). Residence time in lakes: Science, Management, Education J. Limnol., 62 (Suppl. 1), 73-90, 2003 (Vol. 62, 1, 73-90).

Kowalczak, P., Kundzewicz, Z. W. (2011). Water-related conflicts in urban areas in Poland. Hydrological sciences journal, 56(4), 588-596.

Kujawiak, S., Makowska, M., \& Matz, R. (2018). Hydraulic characteristics of the airlift pump. Acta Scientiarum Polonorum. Formatio Circumiectus, 17(4), 85.

Kujawiak, S., Makowska, M., \& Mazurkiewicz, J. (2020). The Effect of Hydraulic Conditions in Barbotage Reactors on Aeration Efficiency. Water, 12(3), 724.

Kujawiak, S., Makowska, M., Matz, R., \& Gawrońska, A. (2017). The efficiency of the aeration process in airlift reactors with moving beds. Technical Transactions, 10(3), 167-172.

Lake, P. S., Bond, N., \& Reich, P. (2007). Linking ecological theory with stream restoration. Freshwater biology, 52(4), 597-615.

Leiknes T. and Ødegaard H. (2007). The development of a biofilm membrane bioreactor. Desalination, 202(1), $135-143$
Li XN, Song HL, Li W, Lu XW, Nishimura O (2010) An integrated ecological floating-bed employing plant, freshwater clam and biofilm carrier for purification of eutrophic water. Ecological engineering, 36, 382-390.

Łopata, M., Wiśniewski, G., Parszuto, K., \& Dunalska, J. A. (2016). From restoration to revitalization: How to recover recreational values of urban lakes. A case study of Lake Domowe Duże in Szczytno. Polish Journal of Natural Sciences, 31(3), 471-483.

Mazur, R., Bedla, D., Chmielowski, K., Nowak, A., \& Mazurkiewicz, J. (2016). The effect of oxygen condition on effectiveness of sewage treatment in submersible technology of nonwoven filters. Przemysl Chemiczny, 95(8), 1513-1517.

Mazur, R. (2019). A. Lakes Restoration: Analysis of Terminology Incorrectly Used in the Scientific Literature. Acta Scientiarum Polonorum. Formatio Circumiectus, 18(2),135-146. https://doi.org/10.15576/ASP. $\mathrm{FC} / 2019.18 .2 .135$

Mazur, R. (2019). B. The Concept of Polluted Small Water Reservoirs Re-Degradation Technology with the Application of MBBR Reactors. Acta Scientiarum Polonorum. Formatio Circumiectus, 18(2), 121-133. https:// doi.org/10.15576/ASP.FC/2019.18.2.121

Mazur, R. (2020). The Application of Microbiological Biopreparations in The Process of Water Remediation of the Dam Reservoir in Głuchów. Acta Scientiarum Polonorum. Formatio Circumiectus, 19(1), 81-95.

Mazur, R., \& Siatarek, M. (2020). Microbiological bioremediation of the Kamienna Gora dam reservoir. Acta Scientiarum Polonorum. Formatio Circumiectus, 19(1).

Mazur, A., Wagner, A., Mazur, R., \& Bedla, D. (2020) B. Bioremediacja mikrobiologiczna zdegradowanych wód jako alternatywa dla metod chemicznego oczyszczania zbiorników wodnych. Przemysł Chemiczny, 99.

Mazur, R., Szoszkiewicz, K., Nowak, A., Pietruczuk, K., \& Chmist, J. (2017). Ecological classification of artificial reservoirs in Polish lowlands according to Water Framework Directive requirements. Polish Journal of Environmental Studies, 26(1), 205-210.

Mazurkiewicz, J., Mazur, A., Mazur, R., Chmielowski, K., Czekała, W., \& Janczak, D. (2020). The Process of Microbiological Remediation of the Polluted Słoneczko Reservoir in Poland: For Reduction of Water Pollution and Nutrients Management. Water, 12(11), 3002.

McQuarrie J. P. and Boltz J. P. (2011). Moving bed biofilm reactor technology: process applications, design, and performance. Water Environment Research,83(6), $560-575$. 
Mazur, A., Chmielowski, K. (2020). Innovative aeration and treatment technologies supporting the process of revitalization of degraded water reservoirs. Acta Sci. Pol., Formatio Circumiectus, 19 (3), 15-28. DOI: http://dx.doi.org/10.15576/ASP.FC/2020.19.3.15

Mingjun S, Yanqiu W, Xue S (2009). Study on bioremediation of eutrophic lake. Journal of Environmental Sciences 21, S8-S16.

Muhammetoğlu, A., Muhammetoğlu, H., \& Soyupak, S. (2002). Evaluation of efficiencies of diffuse allochthonous and autochthonous nutrient input control in restoration of a highly eutrophic lake. Water science and technology, 45(9), 195-203.

Nakamura, K., \& Mueller, G. (2008). Review of the performance of the artificial floating island as a restoration tool for aquatic environments. In World Environmental and Water Resources Congress 2008, Ahupua'A (1-10).

Nasirudin, A., Chao, R. M., Utama, I. K. A. P. (2017). Solar powered boat design optimization. Procedia engineering, 194, 260-267.

Nasr M, Ismail S (2015). Performance evaluation of sedimentation followed by constructed wetlands for drainage water treatment. Sustainable Environment Research, 25, 141-150.

Nowak, A., Mazur, R., Panek, E., \& Chmist, J. (2018). Model Studies on the Effectiveness of MBBR Reactors for the Restoration of Small Water Reservoirs. In E3S Web of Conferences (30, p. 02004). EDP Sciences.

Nowak, A., Mazur, R., Panek, E., Dacewicz, E., Chmielowski, K. (2019). Treatment efficiency of fish processing wastewater in different types of biological reactors. Physics and Chemistry of the Earth, Parts A/B/C, 109, 40-48.

Ødegaard, H., Rusten, B., \& Wessman, F. (2004). State of the art in Europe of the moving bed biofilm reactor (MBBR) process. In Proceedings of the 77th Annual Water Environment Federation Technical Exposition and Conference, New Orleans, Louisiana, Oct (pp. 2-6).

Ondiviela, B., Juanes, J. A., Gómez, A. G., Sámano, M. L., \& Revilla, J. A. (2012). Methodological procedure for water quality management in port areas at the EU level. Ecological Indicators, 13(1), 117-128.

Polkowska, Ż., Kot, A., Wiergowski, M., Wolska, L., Wołowska, K., \& Namieśnik, J. (2000). Organic pollutants in precipitation: determination of pesticides and polycyclic aromatic hydrocarbons in Gdańsk, Poland. Atmospheric Environment, 34(8), 1233-1245.

Pottinger, T. G., Cook, A., Jürgens, M. D., Rhodes, G., Katsiadaki, I., Balaam, J. L., Matthiessen, P. (2011). Effects of sewage effluent remediation on body size, somatic RNA: DNA ratio, and markers of chemical exposure in three-spined sticklebacks. Environment International, 37(1), 158-169.
Robu, B. M., Căliman, F. A., Bețianu, C., \& Gavrilescu, M. (2007). Methods and procedures for environmental risk assessment. Environmental Engineering \& Management Journal (EEMJ), 6(6).

Ruan X, Xue Y, Wu J, Ni L, Sun M, et al. (2006) Treatment of polluted river water using pilot-scale constructed wetlands. Bulletin of environmental contamination and toxicology, 76, 90-97.

Rybicka, E. H. (1996). Impact of mining and metallurgical industries on the environment in Poland. Applied Geochemistry, 11(1-2), 3-9.

Sheng Y, Chen F, Sheng G, Fu J. (2012) Water quality remediation in a heavily polluted tidal river in Guangzhou, South China. Aquatic Ecosystem Health \&Management, 15, 219-226.

Singh, K. P. (1982). Lake restoration methods and feasibility of water quality management in Lake of the Woods. Illinois State Water Survey.

Sitarek, M., Napiórkowska-Krzebietke, A., Mazur, R., Czarnecki, B., Pyka, J. P., Stawecki, K., Kapusta, A. (2017). Application of Effective Microorganisms Technology as a lake restoration tool-a case study of Muchawka Reservoir. Elem, 22(2), 529-543.

Spagnolo, G. S., Papalillo, D., Martocchia, A., \& Makary, G. (2012). Solar-electric boat. Journal of Transportation Technologies, 2(2), 144-149.

Swann, L. (1997). A fish farmer's guide to understanding water quality. Aquaculture Extension, Illinois-Indiana Sea Grant Program.

Tanaka, T., Tsuzuki, K., Nishijima, N., \& Takagi, T. (2001). Algae-removal performance of a fluidized-bed biofilm reactor system for lake water treatment. Water science and technology, 43(1), 277-283.

Van Aalst, M. K., Cannon, T., \& Burton, I. (2008). Community level adaptation to climate change: the potential role of participatory community risk assessment. Global environmental change, 18(1), 165-179.

Wasik, E., Bugajski, P., Chmielowski, K., Nowak, A., Mazur, R. (2017). Crystallization of struvite and hydroxyapatite during removal of biogenic compounds on the filter bed. Przemysl Chemiczny, 96(8), 1739-1743.

Wei, X., YUAN, B., SUN, S. Y., \& ZHU, Y. C. (2004). Progress of Water Pollution Remediation Techniques in City and Town River [J]. Journal of Guangdong University of Technology, 4.

Xiao L, Ouyang H, Li H, Chen M, Lin Q, et al. (2010). Enclosure study on phytoplankton response to stocking of silver carp (Hypophthalmichthys molitrix) in a eutrophic tropical reservoir in South China. International Review of Hydrobiology 95, 428-439. 
Yüksek, A., Okuş, E., Yilmaz, I. N., Aslan-Yilmaz, A., Taş, S. (2006). Changes in biodiversity of the extremely polluted Golden Horn Estuary following the improvements in water quality. Marine Pollution Bulletin, 52(10), $1209-1218$.

Zawadzki, P., Błażejewski, R., Pawlak, M. (2017). Przegląd metod odmulania zbiorników wodnych. Acta Scientiarum Polonorum. Formatio Circumiectus, 16(2), 217-228.
Zdorovennova, G., Palshin, N., Zdorovennov, R., Golosov, S., Efremova, T., Gavrilenko, G., \& Terzhevik, A. (2016). The oxygen regime of a shallow lake. Geography, environment, sustainability, 9(2), 47-57.

Zhao Y., Yang Z., Xia X., Wang F. (2012). A shallow lake remediation regime with Phragmites australis: Incorporating nutrient removal and water evapotranspiration. Water Res, 46, 5635-5644.

\section{INNOWACYJNE SYSTEMY AERACJI I TECHNOLOGIE OCZYSZCZANIA WSPOMAGAJĄCE PROCESY REWITALIZACJI ZDEGRADOWANYCH ZBIORNIKÓW WODNYCH}

\section{ABSTRACT}

\section{Cel pracy}

Celem pracy jest ocena procesu aeracji oraz bioreaktorów MBBR w procesie bioremediacji zanieczyszczonych zbiorników wodnych.

\section{Materiały i metody}

Autorzy przestawili przegląd metod rewitalizacji zbiorników wodnych, które są stosowane w praktyce branżowej. Szczegółowej charakterystyce poddane systemy aeracji drobno i mikropęcherzykowej. Opisano również rolę jaką mogą odgrywać innowacyjne systemy mobilnych platform z bioreaktorami MBBR w rewitalizacji zbiorników wodnych.

\section{Wyniki i wnioski}

Na postawie przestawionych informacji naukowych wskazano, iż zastosowanie efektywnych systemów mikroaeracji oraz aeracji drobnopęcherzykowej bardzo korzystnie wpływa na poprawę efektywności procesów rewitalizacji. Autorzy ocenili, iż wskazane metody mogą jedynie wspomagać główną metodę biologiczną stosowaną w bioremediacji zdegradowanych zbiorników wodnych. Jako główne metody bioremediacji biologicznych założono metody biotechnologiczne oparte na biopreparatach mikrobiologicznych oraz tworzenie ekobarier (ekotonów). Przedstawiono również schemat prototypowej platformy rekultywacyjnej dla zbiorników wodnych.

Stowa kluczowe: MBBR, oczyszczanie wody, rekultywacja zbiorników wodnych, zanieczyszczenia wód 